\title{
The Influence Of The Geological Origin On Soil Volume Change Through Collapse Settlement
}

\author{
George Brink and J Louis van Rooy \\ Department of Geology, University of Pretoria, P/Bag X20 Hatfield 0028; Tel: +27124202023 \\ (E-mail: louis.vanrooy@up.ac.za)
}

\begin{abstract}
:
Partially saturated soils are often dense with a high bearing capacity and will subsequently only suffer small amounts of compression under normal foundation loads. However, when wetted under load many such soils undergo a marked and sudden increase in settlement, the phenomenon that is known as collapse settlement.

It was originally assumed that the collapse phenomenon is largely restricted to loose aeolian deposits, with the result that most of the research and work dealt almost exclusively with such deposits. However, the collapse phenomenon has since been identified in a number of different transported soils as well as residual soils, most notably the residual granitic soils associated with the Basement Complex of South Africa.

Recent studies suggest that the geological origin of the material plays an important role in the collapse mechanism of the particular material. This paper highlights the differences between the collapse process in transported and residual soils by focusing on the geological origin of the material.
\end{abstract}

Keywords: Soil Collapse; Collapse Settlement; Geological Origin, Residual soils

\section{Introduction}

Partially saturated soils are often dense with a high bearing capacity and will subsequently only suffer small amounts of compression under normal foundation loads. However, when wetted under load many such soils undergo a marked and sudden increase in settlement, the phenomenon which is known as collapse settlement (Barden et al., 1973). It should be noted that in the context of this article the term "dense" refers to the overall consistency of a non-cohesive soil (i.e. the resistance of the material to penetration of the sharp end of the geological pick, Brink and Bruin, 2001), and not to the general particle arrangement of the material.

Collapsible soils can be broadly subdivided into two groups; namely wet collapsible soils and dry collapsible soils (Fredlund and Gan, 1995). The focus of this article is restricted to the dry, largely uncemented collapsible soils that commonly occur in southern Africa. Dry collapsible soils are further subdivided into collapsible transported and residual soils. The distribution of collapsible transported soils is virtually unrestricted, whereas the distribution of collapsible residual soils largely coincides with those areas where historically wet climates resulted in deep weathering and leaching of the soil as well as being presently located within areas of annual water surplus.

Much development has taken place on potentially collapsible soils in South Africa, especially on the transported Berea Red Sands, the residual granitic soils of the Highveld (Rust et al., 2005), 
residual Basement Granite soils in the Lowveld (markedly the White River, Tzaneen and Bushbuck Ridge areas) as well as recently on the Kalahari Aeolian Sands in the Lephalale area. Even though levels of development have been intense in such areas, the subject of collapsible soils has not received much attention in South Africa in recent years, with very little being published on the subject since Schwartz's state of the art paper on collapsible soils in 1985 (Schwartz, 1985).

As part of an MSc research project on the influence of suction pressures on the collapse behaviour of different South African soils (Brink, 2012) a number of different transported and residual soils were sampled, analysed and tested. The results suggest that the geological origin of the material plays an important role in the collapse mechanism of the particular material, and that the collapse potential and behaviour will vary depending on the origin of the collapsible material.

\section{Collapse Potential}

\section{Recognition of Collapse Potential}

Numerous definitions describing potentially collapsible soils or the collapse phenomenon exist. Schwartz (1985) defines a collapsible soil as "...a soil which can withstand relatively large imposed stresses with small settlements at a low in-situ moisture content but will exhibit a decrease in volume and associated settlement with no increase in the applied stress if wetting up occurs". Barden et.al (1973) state that for appreciable collapse to occur, the material should have an open, potentially unstable partly saturated structure; a high enough value of applied stress to develop a metastable condition and a high enough value of soil suction to stabilize intergranular contacts and whose reduction on wetting will lead to collapse. In its simplest form the collapse phenomenon may be expressed as the existence of certain conditions in the subsoil structures that may exist where structures have stood satisfactorily for some time and then suddenly experience additional settlement (Jennings and Knight, 1975).

It is clear from these and other definitions that partially saturated soils are the predominant source of collapsible soils, but that no clear definition for collapsible soil exists. Rogers (1995) therefore argues that a better approach might be to list the features most commonly associated with collapsible soils. These include:

- An open soil structure;

- A high void ratio;

- A low dry density;

- A high porosity;

- Geologically young or recently altered deposit;

- High sensitivity and

- Low interparticle bond strength.

For the purpose of this paper the abovementioned typical features are adequate descriptors of the term "collapsible soil" and were also used as identification criteria during the process of collecting representative samples for the laboratory testing process.

According to Brink et. al. (1982) and Schwartz and Yates (1980), the typical dry densities that could be expected for collapsible soils in South Africa range from 900 to $1600 \mathrm{~kg} / \mathrm{m}^{3}$, even 
though collapse in materials with dry densities outside this range cannot be completely excluded (Rust et.al, 2005).

Brink (1985) proposes that a relationship exists between collapse potential and dry density for different materials, which can be represented by the following equations and correlation coefficients:

Aeolian Sands (correlation coefficient $=0.73$ ):

$$
\mathrm{CP}=\frac{1672-\Upsilon \mathrm{d}}{22}
$$

Soils of mixed origin (correlation coefficient $=0.77$ ):

$$
\mathrm{CP}=\frac{1590-\Upsilon \mathrm{d}}{18.9}
$$

From these equations it is evident that aeolian sands with dry densities greater than $1672 \mathrm{~kg} / \mathrm{m}^{3}$ and soils of mixed origin with dry densities greater than $1590 \mathrm{~kg} / \mathrm{m}^{3}$ are generally not regarded as collapsible.

\section{Mechanism of Collapse}

For collapse to take place, the following conditions must be met (Schwartz, 1985):

- The soil must have a collapsible fabric;

- A condition of partial saturation is required;

- There must be an increase in moisture content, which can be considered as the triggering mechanism for collapse to occur;

- The soil needs to be subjected to an applied pressure greater than the overburden pressure before collapse will take place.

Once these conditions for collapse to occur have been attained, the collapse process can be divided into three phases, with all three phases taking place simultaneously (Klukanova and Frankovska, 1995):

- Phase I: This phase represents the initial stage of destruction of the original microstructure due to an increase in moisture and applied stress. Clay films, bridges and buttresses start to break, aggregates and micro-aggregates disintegrate.

- Phase II: Disintegration of the microstructure continues, other fabric elements compress and the total volume of the soil decreases.

- Phase III: At this point a new microstructure develops after collapsing, basic structural units disintegrate, clay particle coatings are destroyed or removed completely and clay particles are aggregated. 
Figure 1 depicts the collapse mechanism for collapsing sand effectively illustrating the process as discussed above.

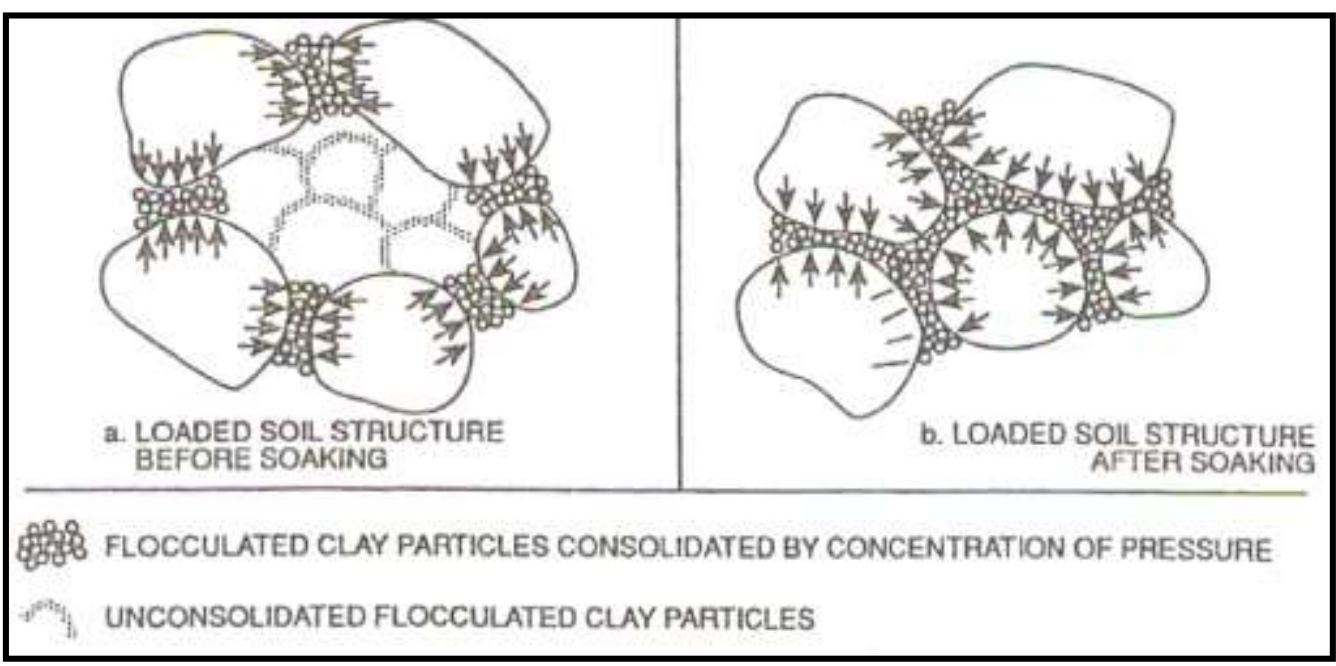

Fig 1: Mechanism of collapse for collapsing sand (Jennings and Knight, 1975 in Rogers, 1995)

\section{Distribution of Collapsible Soils}

According to Schwartz (1985), it was originally assumed that the collapse phenomenon is largely restricted to loose aeolian deposits, with the result that most research and experimental work dealt almost exclusively with such deposits. However, the collapse phenomenon has been identified in a number of different transported and residual soils.

Weinert (1980) devised a climatic zoning for southern Africa with the $\mathrm{N}=5$ contour depicting the boundary between the water deficit area with $\mathrm{N}>5$ and where $\mathrm{N}$ is less than 5 water is available to effect chemical weathering. The vast majority of occurrences of collapsing soils in Southern Africa, either transported or residual, are largely restricted to environments of climatic $\mathrm{N}$-values (Weinert, 1980) between 2 and 5, with very few occurrences of collapse been observed where $\mathrm{N}<2$ and $\mathrm{N}>5$. However, Weinert (1980) attributes this largely to the fact that rates of development have been substantially higher in areas where $2<\mathrm{N}<5$ than in other areas, and therefore more cases of collapse settlement have been reported.

\section{Transported Soils}

Transported soils can be defined as soils that have been moved by a natural agency in recent geological times. Table 1, adapted from Jennings and Brink (1978) lists the origins and transportation agency of various transported soils that are typically prone to exhibit collapse settlement. 
Table 1: Transported soils and commonly associated engineering problems (adapted from Jennings and Brink, 1978 in Schwartz, 1985)

\begin{tabular}{|c|c|c|c|c|}
\hline $\begin{array}{c}\text { Transported Soil } \\
\text { Type }\end{array}$ & $\begin{array}{c}\text { Agency of } \\
\text { Transportation }\end{array}$ & Source & Soil Type & $\begin{array}{c}\text { Problems to } \\
\text { Anticipate }\end{array}$ \\
\hline $\begin{array}{c}\text { Hillwash (fine } \\
\text { colluvium) }\end{array}$ & Sheetwash & $\begin{array}{c}\text { Acid crystalline } \\
\text { rock }\end{array}$ & Clayey sand & $\begin{array}{c}\text { Collapsible grain } \\
\text { structure }\end{array}$ \\
\cline { 3 - 5 } & $\begin{array}{c}\text { Arenaceous } \\
\text { sedimentary rock }\end{array}$ & Sand & $\begin{array}{c}\text { Collapsible grain } \\
\text { structure }\end{array}$ \\
\hline Gulleywash & Gulleywash & Local catchment & $\begin{array}{c}\text { Gravels, sands, silts } \\
\text { or clays }\end{array}$ & $\begin{array}{c}\text { All possible } \\
\text { problems }\end{array}$ \\
\hline Aeolian Deposit & Wind & $\begin{array}{c}\text { Usually mixed } \\
\text { source }\end{array}$ & Sand & $\begin{array}{c}\text { Collapsible grain } \\
\text { structure } \\
\text { Compressibility } \\
\text { Littoral Deposit }\end{array}$ \\
\hline Biotic Soils & Termites & Underlying soil & $\begin{array}{c}\text { Often clayey or } \\
\text { silty sand } \\
\text { structure }\end{array}$ \\
\hline
\end{tabular}

It is obvious that the abovementioned types of transported soils and associated problems can occur almost anywhere in South Africa (Schwartz, 1985).

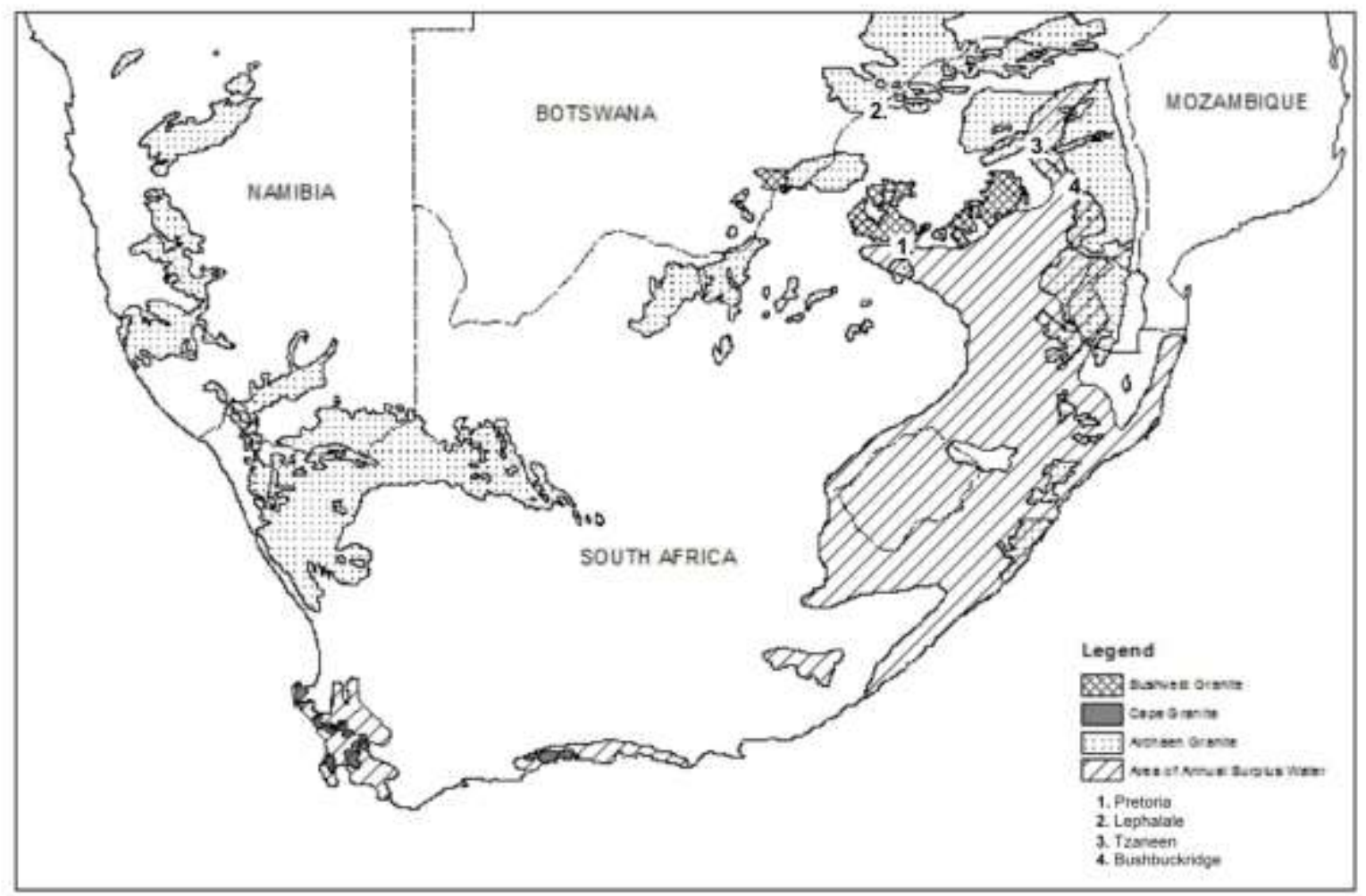

Fig 2: Distribution of collapsing sand (After Jennings and Knight, 1975) 


\section{Residual Soils}

In South Africa, the term "collapsible soil" is most often associated with the residual granitic soils of the Basement Complex (Schwartz, 1985). Extensive foundation problems have been encountered with these soils, both in the Highveld and Lowveld of South Africa.

The collapsible nature of the residual soils derived from these granites is associated with the deeply weathered soil profiles on the African Erosion Surface, encountered in the humid eastern parts of South Africa, typically known as areas of annual water surplus (Figure 2).

During the weathering process, quartz remains unaltered in the form of sand grains, mica particles remain partially unaltered but the feldspars are thoroughly kaolinized through the chemical interaction with water charged with carbon dioxide (Schwartz, 1985), forming what is commonly known as ferralitic soils (Brink, 1979).

As the name suggests, ferralitic soils are rich in iron and aluminium hydroxides. Due to the duration of the weathering cycle and the moist nature of the climate, these ferralitic soils have a very low base status and are characterized by a friable and porous structure and the presence of 1:1 lattice kaolinitic clays (Brink, 1979).

Other residual soils with reported occurrences of a collapsible grain structure include residual Magaliesberg Quartzite, residual granite of the Cape Granite Suite and residual feldspathic sandstones of the Clarens and Elliot Formations. As is the case with the residual granites, the majority of the abovementioned cases fall within or close to areas of annual water surplus, hinting towards the importance of decomposition and leaching in the formation of collapsible residual soils.

\section{Sampling and Testing of Residual and Transported Material}

A number of undisturbed samples of soils that are expected to exhibit collapse behaviour were collected from four localities based on the typical distribution of collapsible soils in South Africa. These included residual granite from Bushbuck Ridge and residual leucocratic granite from Tzaneen in Mpumalanga, aeolian sand from Lephalale in Limpopo and colluvial material from the Magaliesberg quartzite in Pretoria, Gauteng (Fig. 2). The size of the undisturbed block samples cut in the field varied depending on the material characteristics and the ease with which an intact block of material could be cut and removed without breaking. The retrieved block of undisturbed material simply needed to be of sufficient size to cut a number of undisturbed consolidometer ring specimens to use in the consolidometer, as well as for suction measurements.

In the laboratory the samples were prepared for testing in a modified consolidometer. The natural moisture content, dry density, specific gravity, grading, Atterberg Limits and initial void ratio were determined for each of the materials prior to testing. The dry density and initial void ratios of all the materials are summarised in Table 2 and Table 3 below. 
Table 2: Calculated material properties

\begin{tabular}{|c|c|c|c|c|}
\hline Material Property & $\begin{array}{c}\text { Bushbuck Ridge } \\
\text { residual granite }\end{array}$ & $\begin{array}{c}\text { Tzaneen } \\
\text { residual granite }\end{array}$ & $\begin{array}{c}\text { Lephalale } \\
\text { aeolian sand }\end{array}$ & $\begin{array}{c}\text { Magaliesberg } \\
\text { colluvium }\end{array}$ \\
\hline Dry density $\left(\mathrm{kg} / \mathrm{m}^{3}\right)$ & 1392 & 1400 & 1622 & 1650 \\
\hline Initial void ratio & 0.864 & 0.852 & 0.657 & 0.576 \\
\hline Natural moisture content (\%) & 7.15 & 18 & 12.8 & 5.6 \\
\hline Degree of saturation (\%) & 22 & 55.9 & 56.7 & 25.7 \\
\hline
\end{tabular}

Table 3: Grading, Atterberg Limits and material classification

\begin{tabular}{|c|c|c|c|c|c|c|c|c|c|c|c|}
\hline \multirow{2}{*}{$\begin{array}{l}\text { Sample } \\
\text { Name }\end{array}$} & \multirow{2}{*}{ Description } & \multicolumn{4}{|c|}{ Soil composition } & \multicolumn{2}{|c|}{$\begin{array}{c}\text { Atterberg } \\
\text { Limits }\end{array}$} & \multirow{2}{*}{$\begin{array}{c}\mathbf{L S} \\
\%\end{array}$} & \multirow[b]{2}{*}{ GM } & \multirow[b]{2}{*}{ Activity } & \multirow{2}{*}{$\begin{array}{c}\text { AASHTO / } \\
\text { Unified } \\
\text { classification }\end{array}$} \\
\hline & & $\begin{array}{c}\text { Clay } \\
\%\end{array}$ & $\begin{array}{l}\text { Silt } \\
\%\end{array}$ & $\begin{array}{l}\text { Sand } \\
\%\end{array}$ & $\begin{array}{c}\text { Gravel } \\
\%\end{array}$ & LL & $\begin{array}{l}\text { PI } \\
\%\end{array}$ & & & & \\
\hline $\begin{array}{c}\text { Bushbuck } \\
\text { Ridge residual } \\
\text { granite }\end{array}$ & $\begin{array}{l}\text { Light orange } \\
\text { red silty } \\
\text { sand }\end{array}$ & 11 & 20 & 57 & 12 & 36 & 13 & 6.0 & 1.25 & Low & $\begin{array}{c}\text { A-2-6 (1) / } \\
\text { SC }\end{array}$ \\
\hline $\begin{array}{c}\text { Tzaneen } \\
\text { residual } \\
\text { granite }\end{array}$ & $\begin{array}{l}\text { Light brown } \\
\text { silty sand }\end{array}$ & 3 & 36 & 60 & 1 & 43 & 6 & 2.0 & 0.89 & Low & A-5 (0) / SM \\
\hline $\begin{array}{c}\text { Lephalale } \\
\text { Aeolian Sand }\end{array}$ & $\begin{array}{c}\text { Dark red } \\
\text { clayey sand }\end{array}$ & 14 & 11 & 71 & 4 & 20 & 6 & 3.0 & 1.17 & Low & $\begin{array}{l}\text { A-2-4 (0) / } \\
\text { SM \& SC }\end{array}$ \\
\hline $\begin{array}{c}\text { Magaliesberg } \\
\text { Colluvium }\end{array}$ & $\begin{array}{l}\text { Dark brown } \\
\text { clayey sand }\end{array}$ & 17 & 17 & 66 & 0 & 22 & 8 & 4.0 & 0.78 & Low & $\mathrm{A}-4(0) / \mathrm{SC}$ \\
\hline
\end{tabular}

Samples were also subjected to optical microscope analysis in an effort to compare the change in structure before and after consolidation and the images are displayed in Figure 3. 


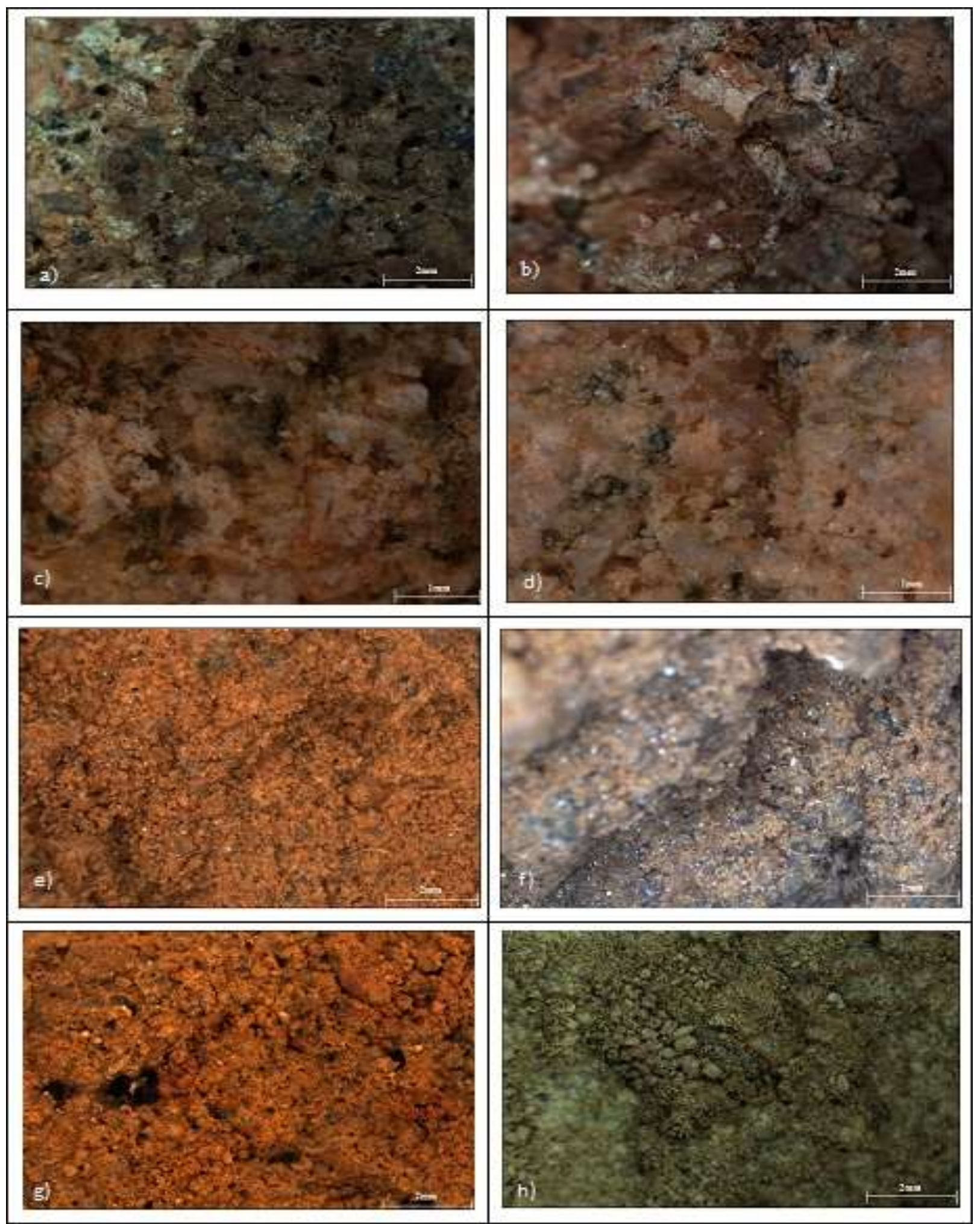

Fig 3: (from top left to bottom right): Bushbuck Ridge residual granite a) before consolidation and b) after consolidation; Tzaneen leucocratic granite c) before consolidation and d) after consolidation; Lephalale aeolian sand e) before consolidation and f) after consolidation and Magaliesberg colluvium g) before consolidation and $h$ ) after consolidation. 
The test samples were cut and secured in the loading cell which was modified to allow for the accurate and incremental addition of moisture during the consolidation process.

Once the test setup had been completed, the sample in the cell was loaded incrementally up to $200 \mathrm{kPa}$. Settlement readings (millimetre settlement) were taken immediately once the sample was loaded, and then at hourly intervals. The load was only increased to the next level once the rate of creep of the sample was equal to or less than $0.25 \%$ of the original height of the sample (Rust et.al, 2005). Thus, if the original sample height was 20 millimetres, the load was increased once the rate of creep was equal to or less than 0.05 millimetres per hour. Up to this point the testing procedure was similar to that of the standard Collapse Potential Test (Jennings \& Knight, 1975). Once the sample had been successfully loaded up to $200 \mathrm{kPa}$ it was left overnight to ensure that it was completely consolidated before additional moisture was added. It should be emphasised that up to a load of $200 \mathrm{kPa}$ no change had been made to the natural moisture content of the sample through the addition or evaporation of water.

At $200 \mathrm{kPa}$ the moisture content of the material was increased incrementally by adding additional water through the modified loading cell. Once the material reached a level of saturation where additional moisture no longer had any effect on the settlement behaviour of the material the sample was inundated and left overnight before loading was continued to the final load of $800 \mathrm{kPa}$. Loading of the Magaliesburg test specimen was however terminated at $400 \mathrm{kPa}$ due to a technical problem with the apparatus once this load was surpassed during the particular test

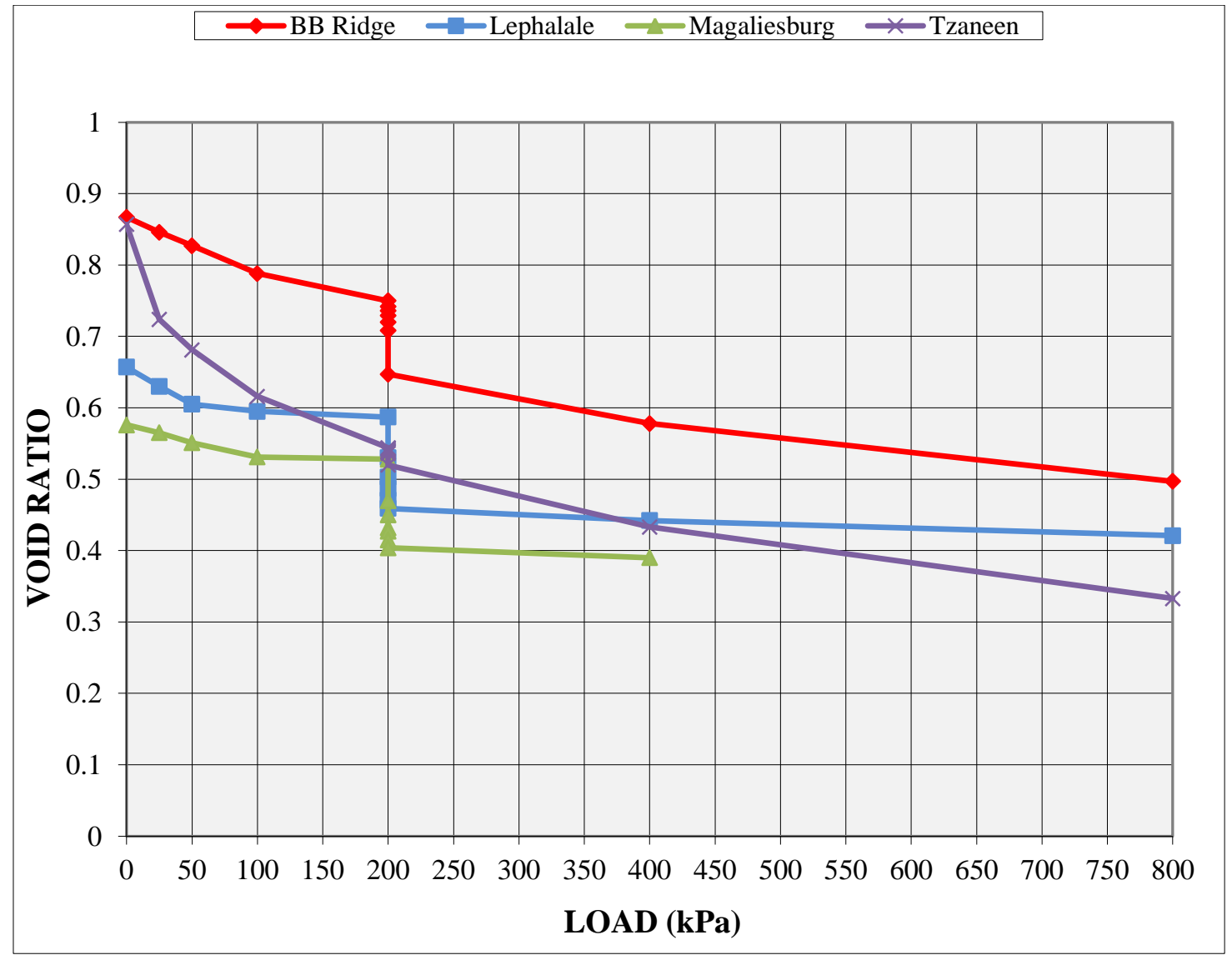

Fig 4: Change in void ratio of transported and residual materials with increase in load and saturation at $200 \mathrm{kPa}$ 


\section{Discussion}

From the available test data and microscope analysis a distinct difference was noted in the consolidation behaviours of the residual and transported materials.

From the microscope analysis and photographs a definite change in structure was noticed after consolidation for all the materials. The most noticeable was that, in the residual materials there was a significant decrease in the number of visible voids in the material after consolidation had taken place, with the average void size or dimensions observed from the microscope photography remaining constant. This suggested that volume change through collapse settlement in the residual material was governed by the total collapse of some voids whilst others remained unchanged following an increase in moisture content or applied stress. Relatively similar behaviour was noticed in the transported material, but to a significantly smaller degree with the majority of the existing voids being totally closed.

It is evident from the calculated material properties that the dry densities and void ratios of the transported aeolian and colluvial material differ from those of the residual granitic material. The transported materials have higher dry densities and lower initial void ratios than the residual materials. However, after the materials had been subjected to the full range of stresses and moisture content changes, the transported soils experienced a similar or even greater decrease in void ratio than the residual material (Table 4).

Table 4: Change in void ratio on saturation

\begin{tabular}{|c|c|c|c|c|}
\hline Material Property & $\begin{array}{c}\text { Bushbuck Ridge } \\
\text { residual granite }\end{array}$ & $\begin{array}{c}\text { Tzaneen } \\
\text { residual granite }\end{array}$ & $\begin{array}{c}\text { Lephalale } \\
\text { aeolian sand }\end{array}$ & $\begin{array}{c}\text { Magaliesberg } \\
\text { colluvium }\end{array}$ \\
\hline $\begin{array}{c}\text { Void ratio at 200 kPa: Before } \\
\text { saturation }\end{array}$ & 0.75 & 0.55 & 0.59 & 0.52 \\
\hline $\begin{array}{c}\text { Void ratio at 200 kPa: After } \\
\text { saturation }\end{array}$ & 0.65 & 0.51 & 0.45 & 0.41 \\
\hline
\end{tabular}

This change in void ratio behaviour can most likely be attributed to the remnant structure in the residual materials contributing to the strength of the material and, to a lesser extent, the grain shape of the transported materials allowing for a closer packing of grains under an applied stress. Transported materials are expected to have more rounded grain shapes than the residual materials due to the action of the transport agent affecting their friction angles. This implies that a residual soil and transported soil with the same initial void ratio will not exhibit similar collapse behaviour under similar loads and that a transported soil, with a lower initial void ratio, might exhibit the same or greater amounts of collapse than a residual soil with a similar void ratio. This, however, means that the residual material should still be considered to have a remnant collapse potential due to the remaining voids, which seems to be larger than the collapsed transported soils.

\section{Conclusion}

It is suggested that the geological origin of the material plays a role in its collapse behaviour. The transported materials investigated during this study have higher dry densities and lower initial void ratios than the residual materials. However, after the materials have been subjected to the full range of stresses and moisture content changes the transported soils experienced a similar 
or even greater decrease in void ratio than the residual material. This is attributed to the remnant structure in the residual materials contributing to the strength of the material and, to a lesser extent, the grain shape of the transported materials allowing for a closer packing of grains under an applied stress. This implies that a residual soil and transported soil with the same initial void ratio will not experience similar amounts of collapse.

\section{References}

Barden, L., McGown, A. and Collins, K. (1973). The Collapse Mechanism in Partly Saturated Soil. Eng. Geol., Volume 7, pp. 49-60.

Brink, A.B.A., Partridge, T.C. and Williams, A.A.B. (1982). Soil Survey for Engineering, Oxford University Press.

Brink, A.B.A. (1979). Engineering Geology of Southern Africa, Volume 1, Building Publications, Pretoria.

Brink, A.B.A. (1985). Engineering Geology of Southern Africa, Volume 4, Building Publications, Pretoria.

Brink, A.B.A. and Bruin, R.M.H., (Editors), 2001. Guidelines for soil and rock logging in South Africa. $2^{\text {nd }}$ Impressions, 2001, Proceedings, Geoterminology Workshop organised by AEG, SAICE and SAIEG, 1990.

Brink, G.E. (2012). The Influence of Soil Suction on the Collapse Settlement of Different Soils in South Africa. MSc. Thesis, University of Pretoria, Pretoria.

Fredlund, D.G. and Gan, J. K-M. (1995). The Collapse Mechanism of a Soil Subjected to OneDimensional Loading and Wetting. In: Derbyshire, E., Dijkstra, T. and Smalley, I.J. (eds.) (1995). Genesis and Properties of Collapsible Soils, NATO ASI Series, Kluwer Academic Publishers, pp. 173205.

Jennings, J.E. and Knight, K. (1975). A Guide to Construction On or With Materials Exhibiting Additional Settlement Due to Collapse of Grain Structure, Proc. Sixth Regional Conference for Africa on Soil Mechanics and Foundation Engineering, Durban, South Africa, pp. 99-105.

Klukanova, A., and Frankovska, J. (1995). The Slovak Carpathians loess sediments, their fabric and properties. Genesis and Properties of Collapsible Soils, Derbyshire et al. (Eds.), pp. 129-147.

Rogers, C.D.F. (1995). Types and Distribution of Collapsible Soils. In: Derbyshire, E., Dijkstra, T. and Smalley, I.J. (eds.) (1995). Genesis and Properties of Collapsible Soils, NATO ASI Series, Kluwer Academic Publishers, pp. 173-205.

Rust, E., Heymann, G. and Jones, G. A. (2005). Collapse potential of partly saturated sandy soils from the east coast of Southern Africa. Journal of the South African Institution of Civil Engineering, Vol 47, no 1 , pp. 8 - 14.

Schwartz, K. (1985). Collapsible Soils: Problems of Soils in South Africa, state-of-the-art. The Civil Engineer in South Africa, 27, pp. 379-393.

Schwartz, K. and Yates, J.R.C. (1980). Engineering Properties of Aeolian Kalahari Sands. Proceedings of the Seventh International Conference on Soil Mechanics and Foundation Engineering, Accra.

Weinert, H.H. (1980). The Natural Road Construction Materials of Southern Africa. H\&R Academica, Cape Town, ISBN 086874047 0, pp.231-238. 